\title{
Taxonomic Status of Micrococcus luteus (Schroeter 1872) Cohn 1872, and Desig- nation of the Neotype Strain
}

\author{
M. KOCUR, ZDENA PÁČOVÁ, and T. MARTINEC \\ Czechoslovak Collection of Microorganisms, J. E. Purkyně University, Brno, Czechoslovakia \\ An amended description of Micrococcus luteus (Schroeter 1872) Cohn 1872, \\ at present a broad-based species characterized primarily on negative character- \\ istics, is proposed on the basis of a taxonomic analysis of 30 strains. CCM 169 \\ (= ATCC 4698) is designated as the neotype strain of $M$. luteus.
}

A large number of species of aerobic, catalase-positive, yellow-pigmented micrococci have been described, but their incomplete characterization has hindered their classification. Some of them are known as Micrococcus luteus, $M$. flavus, $M$. lysodeikticus, Sarcina lutea, and $S$. flava. At present only two of these are generally accepted: $M$. luteus and $M$. varians $(13,21)$.

Although $M$. luteus is the type species of the genus Micrococcus, it is not sufficiently defined. At present it is a broad-based species characterized almost solely on negative characters $(3,19)$. The purpose of this paper is to give an amended characterization of $M$. luteus.

\section{MATERIALS AND METHODS}

Bacterial strains. Thirty-one strains of aerobic yellow-pigmented micrococci were investigated, all from the Czechoslovak Collection of Microorganisms, Brno (Table 1). A number of strains originally identified as nonpigmented strains of $M$. luteus were initially included among the strains studied. However, a detailed examination of these organisms (including deoxyribonucleic acid [DNA] base composition and type of peptidoglycan in the cell wall) showed that they were coagulase-negative staphylococci. Nonpigmented strains of $M$. luteus are rarely encountered.

Media and methods. The strains were maintained on nutrient agar at $4 \mathrm{C}$. For morphological, cultural, and biochemical studies, an incubation temperature of 30 C was used.

The methods used were described previously (19, $20,21)$.

\section{RESULTS}

Morphology. All of the strains studied were gram-positive cocci measuring 0.9 to $1.8 \mu \mathrm{m}$ in diameter and arranged in tetrads and in irregular clumps of tetrads. Strains CCM 248, 337,1674 , and 2494 formed packets and irregular clusters of packets. These strains also produced the largest cells ( 1.5 to $1.8 \mu \mathrm{m})$ of all of those studied. None of the strains was motile or produced spores.

Cultural characteristics. Colonies of all of the strains were circular, convex, and smooth, with either a glistening or a dull surface. Tetrad-and packet-forming strains produced matted colonies. All of the strains formed a yellow or greenish-yellow, water-insoluble pigment on most solid media tested. Five strains (CCM 247, $622,851,852$, and 853 ) produced also a yellow, water-insoluble pigment and a violet, water-soluble pigment when grown on yeastglucose agar. Strain CCM 2506 produced a brown extracellular pigment on nutrient agar. In nutrient broth all strains produced a slight turbidity and sediment.

Biochemical characteristics. The biochemical characteristics of the 30 strains regarded here as belonging to M. luteus are given in Table 2 . The 30 strains formed a homogeneous group with an average of $72.4 \%$ guanine plus cytosine (GC) in the DNA. All of the strains hydrolyzed gelatin, were sensitive to lysozyme, and failed to attack carbohydrates or reduce nitrates. As mentioned below, one of the strains (CCM 810) included in this study does not appear to be related to the other strains studied and has therefore not been included in Table 2 .

\section{DISCUSSION}

Thirty of the 31 strains studied formed a relatively homogeneous group possessing the 
TABLE 1. List of strains studied

\begin{tabular}{|c|c|c|}
\hline Organism & CCM no. & Other numbers or names ${ }^{a}$ \\
\hline Micrococcus luteus & 810 & $\begin{array}{l}\text { ATTC } 398=\text { NCIB } 8165=\text { NCTC } 8512=\text { IFO } 3763= \\
\text { IAM } 1097=\text { G. J. Hucker no. } 426 . \text { Suggested neotype }\end{array}$ \\
\hline M. luteus & 309 & \\
\hline M. flavocyaneus & 622 & V. B. D. Skerman No. 30 \\
\hline M. flavocyaneus & $851 ; 852 ; 853$ & C. B. van Niel no. L.A. 8.2 ; L.A. 9.1 ; L.A. 8.1 \\
\hline M. flavus & $210 ; 555$ & $\begin{array}{l}\text { ATCC } 400=\text { NCTC } 2678=\text { G. J. Hucker no. } 196 ; \text { ATCC } \\
10240 a=\text { NCIB } 10419\end{array}$ \\
\hline M. lysodeikticus & 169 & $\begin{aligned} \text { ATCC } 4698 & =\text { NCIB } 9278=\text { NCTC } 2665=\text { IAM } 1056= \\
\text { IFO } 3333 & =\text { CIP A-270 }=\text { NRRL B-287 }\end{aligned}$ \\
\hline M. lysodeikticus & 1335 & H. B. Naylor No. $53-20$ \\
\hline M. lysodeikticus & 2508 & ATCC 12698 \\
\hline M. sodonensis & 144 & $\begin{array}{l}\text { ATCC } 11880=\text { NCIB } 8854=\text { CIP } 55.98=S . \text { Aaronson } \\
\text { strain B }\end{array}$ \\
\hline Sarcina citrea & 248 & \\
\hline S. exigua & 1569 & G. Müller IMB 3072 \\
\hline S. flava & 1674 & CRIPP A-121 \\
\hline S. flava & 351 & ATCC 540 \\
\hline S. flava & 2507 & ATCC $147=$ NRRL B-2617 \\
\hline S. lutea & 409 & A. Kocková-Kratochvílová strain B 14 \\
\hline S. lutea & 149 & ÚEM Sar. $1 / 43$ \\
\hline S. lutea & 337 & ATCC $382=$ AMNH 208; G. J. Hucker strain S82 \\
\hline S. lutea & 410 & ATCC $272=$ NRRL B-2618 \\
\hline S. lutea & 559 & ATCC $381=$ G. J. Hucker strain S66 \\
\hline S. lutea & 2491 & ATCC $15220=$ PCI $1002=$ Hoffman La Roche no. 102 \\
\hline S. lutea & 2506 & ATCC $10054=$ PCI 1000 \\
\hline S. lutea & 2494 & ATCC 10773 \\
\hline S. marginata & 265 & IFO 3066 \\
\hline S. pelagia & 331 & ATCC $14408=$ C. E. ZoBell strain No. 64.2 \\
\hline S. subflava & 1048 & $\begin{array}{l}\text { ATCC } 7468=\text { NCIB } 8942=\text { NRRL B- } 2619=\text { PCI } 1009= \\
\text { WHO } 1=\text { W. C. Tobie strain Mercedita }\end{array}$ \\
\hline S. variabilis & 266 & IFO 3067 \\
\hline Staphylococcus afermentans & 247 & ATCC $8673=$ NCTC 7011 \\
\hline S. afermentans & 2266 & NCTC 7563 \\
\hline
\end{tabular}

${ }^{a}$ Abbreviations: AMNH, American Museum of Natural History, New York, N.Y., USA; ATCC, American Type Culture Collection, Rockville, Md., USA; CCM, Czechoslovak Collection of Microorganisms, J. E. Purkyne̊ University, Brno, CSSR; CIP, Collection of the Pasteur Institute, Paris, France; CRIPP, Central Research Institute of Plant Production, Prague, CSSR; IAM, Institute of Applied Microbiology, Tokyo, Japan; IFO Institute for Fermentation, Osaka, Japan; NCIB, National Collection of Industrial Bacteria, Aberdeen, Scotland; NCTC, National Collection of Type Cultures, London, England; NRRL, Northern Utilization Research and Development Division, U.S. Department of Agriculture, Peoria, Ill., USA; PCI, Penicillin Control and Immunology Section, Food and Drug Administration, Washington, D.C., USA; UEM, Institute of Epidemiology and Microbiology, Prague, CSSR.

following characteristics. (i) The GC content of their DNA ranges from 70 to $75.5 \%(5,6,7$, $27,28)$; (ii) the peptidoglycan of their cell walls is of the L-Lys-peptide subunit type $(29,30$; Kandler, personal communication); (iii) they produce a yellow, water-insoluble pigment; (iv) they do not attack glucose; (v) they are sensitive to lysozyme. In addition, $61 \%$ of the strains produced transformants with $M$. luteus strain ISU (= ATCC 27141) (17; Kloos, personal communication), which confirms their genetic relationship to each other, and $51 \%$ of the strains produced hydrogenated menaquinones (16).
The results of some of the other biochemical tests were the same for all of the strains (Table 2 ). Only seven tests varied from strain to strain, and of these the most variable were urease production and starch hydrolysis.

The strains used in this study were previously identified as belonging to various species of three different genera (see Table 1), but we propose to consider all of them (except CCM 810 , see below) as belonging to the species $M$. luteus. This proposal is in agreement with the views of other authors $(3,4,13,30)$.

In the absence of type strains, authentic strains (i.e., strains of the authors who origi- 
TABLE 2. Biochemical characteristics and GC composition of 30 strains of Micrococcus luteus ${ }^{a}$

\begin{tabular}{|c|c|c|c|c|c|c|c|}
\hline CCM no. & $\begin{array}{c}\% \mathrm{GC} \\
\text { in DNA }\end{array}$ & $\begin{array}{c}\mathrm{pH} \text { in glucose } \\
\text { medium after } \\
6 \text { days } \\
\text { (aerobic) }\end{array}$ & Oxidase & Urease & Tween 80 & $\begin{array}{c}\text { Starch } \\
\text { hydrolysis }\end{array}$ & $\begin{array}{l}\text { Growth in } \\
10 \% \mathrm{NaCl}\end{array}$ \\
\hline 2508 & 70.7 & 7.0 & - & - & - & - & - \\
\hline 247 & 70.8 & 7.2 & + & + & - & - & - \\
\hline 851 & $71.3^{b}$ & 7.1 & + & + & - & + & - \\
\hline 852 & $71.3^{b}$ & 6.7 & + & + & - & - & - \\
\hline 351 & 71.5 & 6.4 & - & - & - & + & - \\
\hline 1674 & 71.5 & 7.6 & - & + & - & - & + \\
\hline 2507 & 71.5 & 6.2 & - & - & - & + & - \\
\hline 2506 & 71.6 & 6.6 & - & + & - & + & - \\
\hline 144 & $71.8^{b}$ & 7.9 & - & - & - & - & + \\
\hline 853 & $72.0^{b}$ & 6.9 & + & + & - & + & - \\
\hline 1335 & $72.0^{b}$ & 7.8 & - & + & + & - & - \\
\hline 622 & $72.0^{b}$ & 6.8 & + & + & - & $\cdot$ & - \\
\hline 266 & $72.3^{b}$ & 7.3 & + & - & - & - & - \\
\hline 337 & 72.3 & 7.3 & - & + & - & - & - \\
\hline 2491 & 72.4 & 6.9 & - & - & - & $\cdot$ & - \\
\hline 210 & $72.8^{b}$ & 7.2 & + & - & + & - & - \\
\hline 169 & $72.8^{c}$ & 7.9 & + & + & - & - & - \\
\hline 559 & $72.8^{b}$ & 7.9 & + & - & - & - & - \\
\hline 265 & $72.8^{b}$ & 7.2 & + & + & - & - & - \\
\hline 331 & 72.8 & 7.8 & - & - & + & - & + \\
\hline 2266 & $72.8^{c}$ & 7.3 & + & - & - & - & + \\
\hline 248 & $73.3^{b}$ & 6.7 & + & - & - & - & + \\
\hline 309 & $73.3^{b}$ & 6.9 & + & - & + & - & - \\
\hline 1048 & 73.4 & 6.9 & + & + & + & - & + \\
\hline 410 & 73.7 & 6.8 & + & + & - & • & + \\
\hline 1569 & 73.8 & 7.1 & + & + & - & - & + \\
\hline 2494 & 73.8 & 6.9 & + & + & - & + & - \\
\hline 555 & 74.0 & 6.7 & + & - & - & + & + \\
\hline 149 & 74.6 & 7.0 & + & - & - & - & - \\
\hline 409 & 75.5 & 7.2 & + & + & - & - & + \\
\hline
\end{tabular}

${ }^{a}$ All strains studied had positive catalase and benzidine tests, hydrolyzed gelatin, produced a yellow, water-insoluble pigment, and grew on solid media with $7.5 \% \mathrm{NaCl}$ and at $37 \mathrm{C}$. None of the strains studied produced free or bound coagulase, produced acid from glucose, mannitol, lactose, maltose, sucrose or fructose (aerobically or anaerobically), produced acetoin, phosphatase, or hemolysis, reduced nitrate, split arginine, grew on solid media with $15 \% \mathrm{NaCl}$ or on Simmons citrate agar, or gave a positive egg-yolk reaction. Reaction: + , positive; $\cdot$, weak; - , negative.

${ }^{b}$ Data by Rosypalová et al. $(27,28)$.

${ }^{c}$ Data by Silvestri and Hill (33). The remaining data on the GC contents are by Boháček et al. (5-7).

nally named the species) of Sarcina pelagia ZoBell and Upham 1944, Micrococcus sodonensis Aaronson 1955, and Sarcina exigua Müller 1961 were included in the set of strains studied. These strains and the original descriptions (which serve as the nomenclatural types in the absence of type strains) of the species in which these strains initially were placed agree with the characteristics of $M$. luteus. Therefore we regard the above-mentioned names as subjective synonyms of $M$. luteus.

In addition, a comparison of the original descriptions of the species Micrococcus flavus Trevisan 1889, Staphylococcus flavocyaneus Knaysi 1942, and Micrococcus polychromus Makarova 1949 show that they too are in accordance with the amended description of $M$. luteus given below. Therefore these names are also regarded here as subjective synonyms of $M$. luteus.

The characteristics of the 30 strains were compared with those of Micrococcus luteus ATCC 398 (= CCM 810), previously suggested (8) as the neotype strain for this species. This strain differs from the 30 strains studied in the following respects. (i) It has a lower GC content $(65 \%)$ of the DNA $(2,27)$; (ii) it has a different menaquinone pattern (16); (iii) it does not produce prototrophic transformants when crossed with M. luteus strain ATCC 27141 (17); and (iv) its peptidoglycan of the L-LysGly-L-Glu type is different from that of 
other yellow-pigmented cocci (25). These differences strongly suggest that ATCC 398 is not related to the other strains included in this study.

Although ATCC 398 has been suggested (8) as the neotype strain of $M$. luteus, neither this nor any other strain has been designated as the neotype of this species in conformance with the international rules of bacteriological nomenclature. Therefore we designate CCM 169, also known as M. lysodeikticus ATCC 4698 and as Staphylococcus afermentans NCTC 2665, as the neotype strain of $M$. luteus. The characters of this strain, given below, agree with those in the original description (31) as well as with those of the current concept of $M$. luteus. ATCC 4698 (= NCTC 2665) has also been designated as the type strain (34) of $M$. lysodeikticus Fleming and as the type strain (32) of Staphylococcus afermentans Castellani. Because these three names are all based on the same type, they are objective synonyms, and the specific epithet luteus (1872) has priority over both lysodeikticus (1922) and aftermentans (1951).

Since the original description of $M$. luteus is not sufficient in terms of present knowledge, we suggest that it be amended as follows:

Micrococcus luteus (Schroeter 1872) Cohn $1872,153$.

Objective synonyms:

Bacteridium luteum Schroeter 1872, 126.

Micrococcus lysodeikticus Fleming, 1922, 306.

Staphylococcus afermentans Castellani 1951, 1022.

Staphylococcus luteus (Schroeter) Wood 1952, 209.

Micrococcus afermentans (Castellani 1951) Pike, 1965, 317.

Subjective synonyms:

Micrococcus flavus Trevisan, 1889, 34.

Staphylococcus flavocyaneus Knaysi, 1942, 367.

Sarcina pelagia ZoBell and Upham, 1944, 279.

Micrococcus polychromus Makarova, 1949, 162.

Micrococcus sodonensis Aaronson, 1955, 67. Sarcina exigua Müller, 1961, 525.

lu'te.us. L. adj. luteus golden yellow.

(Percentages in parentheses below indicate number of strains studied which are positive for the character cited).

Spheres, 0.9 to $1.8 \mu \mathrm{m}$ in diameter, occurring in clumps, tetrads, or packets and in irregular clusters of tetrads and packets. Nonmotile.
Nonsporeforming. Gram-positive. The cell wall peptidoglycan is of the L-Lys-peptide subunit type $(29,30$; Kandler, personal communication).

Agar colonies: Circular, entire, convex, smooth and glistening or matted and granular. A yellow or yellowish green, water-insoluble pigment is produced. Occasional strains may produce a violet or brown, water-soluble pigment in addition to a yellow, water-insoluble pigment.

Agar slant: Good growth with a yellow or yellowish green, water-insoluble pigment.

Nutrient broth: Slight turbidity and sediment are formed.

Chemoorganotrophic: Metabolism is respiratory.

Acid and gas not produced from glucose or other carbohydrates in standard medium (method of Subcommittee [36]).

Catalase is produced $(100 \%)$.

Porphyrin respiratory enzymes are produced $(100 \%)$ (method of Deibel and Evans [12]).

Nutritional requirements: Most laboratory strains require adenine or its precursors. Most strains require biotin and glutamate. Certain strains require aromatic amino acids and less commonly other amino acids (Kloos, personal communication).

Final $p \mathrm{H}$ in glucose broth, 6.8 to 7.9 .

Acetylmethylcarbinol not produced.

Methyl red test is negative.

Ammonium tartrate not utilized.

Indole and hydrogen sulfide not produced.

Ammonia not produced from arginine.

Nitrates usually not reduced.

Nitrites not reduced.

Gelatin hydrolyzed (99\%) (method of Clarke [10]).

Starch hydrolyzed by some strains (30\%).

Esculin not hydrolyzed.

Oxidase produced (60\%) (method of Gaby and Hadley [15]).

Simmons' citrate: No growth.

Phenylalanine deaminase and phosphatase not produced.

Nucleoside transphosphorylase not produced (22).

Egg-yolk reaction negative.

Tween 80 may be split ( $20 \%$ ).

Urease produced $(50 \%)$.

Human and rabbit plasmas not coagulated.

Haemolysis not produced.

Pigment: Produce a yellow or yellowish green, water-insoluble carotenoid (35). Some strains produce a violet or brown, water-insoluble pigment; pink and orange mutants may occur.

Produce hydrogenated menaquinones (16). 
Aerobic.

Good growth between 22 and $37 \mathrm{C}$.

Good growth on solid medium with 0 to $7.5 \% \mathrm{NaCl}$.

Susceptibility to antibiotics: Most strains are susceptible to penicillin, streptomycin, chloramphenicol, neomycin, and lysozyme.

Saprophytic.

Habitat: Soil, water, and skin of humans and other animals.

GC content of the DNA is 70 to 75.5 moles\% $(2,5-7,27,28)$.

Description of ATCC 4698 (= CCM $169=$ NCIB $9278=$ NCTC $2665=$ NRRL B-287), the neotype strain of Micrococcus luteus: Spheres, 0.9 to $1.1 \mu \mathrm{m}$ in diameter, occurring in pairs or clumps. Nonmotile. Nonsporeforming. Gram positive.

The cell wall peptidoglycan is of the L-lysine-peptide subunit type (30).

Agar colonies: Circular, entire, convex, smooth, and glistening. A yellow, water-insoluble pigment is produced.

Nutrient broth: Slight turbidity and sediment are formed.

Chemoorganotroph: Metabolism is respiratory.

Strictly aerobic.

Good growth between 22 and $37 \mathrm{C}$.

The biochemical characteristics and the GC composition of the DNA of this strain are given in Table 2.

Phage host.

Antibiotic susceptibility: susceptible to penicillin, streptomycin, chloramphenicol, tetracycline, ery thromycin, and lysozyme.

$M$. luteus can be distinguished from another yellow-pigmented micrococcus, $M$. varians, by the production of acid from glucose aerobically and the reduction of nitrate. Both tests are negative with $M$. luteus and positive with $M$. varians. The differentiation of $M$. luteus from other Micrococcus species was discussed previously (21).

\section{LITERATURE CITED}

1. Aaronson, S. 1955. Biotin assay with a coccus, Micrococcus sodonensis, nov. sp. J. Bacteriol. 69: 67-69.

2. Auletta, A. E., and E. R. Kennedy. 1966. Deoxyribonucleic acid base composition of some members of the Micrococcaceae. J. Bacteriol. 92:28-34.

3. Baird-Parker, A. C. 1965. The classification of staphylococci and micrococci from world-wide sources. J. Gen. Microbiol. 38:363-387.

4. Baird-Parker, A. C. 1970 . The relationship of cell wall composition to the current classification of staphylococci and micrococci. Int. J. Syst. Bacteriol. 20:483-490.
5. Boháček, J., M. Kocur, and T. Martinec. 1967. DNA base composition and taxonomy of some micrococci. J. Gen. Microbiol. 46:369-376.

6. Boháček, J., M. Kocur, and T. Martinec. 1970. DNA base composition of some Micrococcaceae. Microbios 6:85-91.

7. Boháček, J., M. Kocur, and T. Martinec. 1972. Deoxyribonucleic acid base composition of yellow pigmented micrococci. Zentralbl. Bakteriol. Parasitenk. Infektionskr. Hyg. Abt. 2, in press.

8. Breed, R. S. 1952. The type species of the genus Micrococcus. Int. Bull. Bacteriol. Nomencl. Taxon. 2:85-88.

9. Castellani, A. 1951. Staphylococci and their classification. In C. Shaw, J. M. Stitt, and S. T. Cowan (ed.). J. Gen. Microbiol. 5:1010-1023.

10. Clarke, S. 1953. A simplified plate method for detecting gelatine liquefying bacteria. J. Clin. Pathol. 6:246-248.

11. Cohn, F. 1872. Untersuchungen über Bakterien. Beitr. Biol. Pflanz. 1:127-244.

12. Deibel, R. H., and J. B. Evans. 1960. Modified benzidine test for the detection of cytochromecontaining respiratory systems in microorganisms. J. Bacteriol. 79:356-360.

13. Evans, J. B. 1965. Current views and problems relating to the taxonomy of the Micrococcaceae. Int. Bull. Bacteriol. Nomencl. Taxon. 15:111-112.

14. Fleming, A. 1922. On a remarkable bacteriolytic element found in tissues and secretions. Proc. Roy. Soc. Ser. B. 93:306-317.

15. Gaby, W. L., and C. Hadley. 1957. Practical laboratory test for the identification of Pseudomonas aeruginosa. J. Bacteriol. 74:356-358.

16. Jeffries, L., M. A. Cawthorne, M. Harris, B. Cook, and A. T. Diplock. 1969. Menaquinone determination in the taxonomy of Micrococcaceae. J. Gen. Microbiol. 54:365-380.

17. Kloos, W. E. 1969. Transformation of Micrococcus lysodeikticus by various members of the family Micrococcaceae. J. Gen. Microbiol. 59:247-255.

18. Knaysi, G. 1942. The demonstration of a nucleus in the cell of a Staphylococcus. J. Bacteriol. 43:365-386.

19. Kocur, M., and T. Martinec. 1962. A taxonomic study of the genus Micrococcus (in Czech). Folia Fac. Sci. Natur. Univ. Purkynianae Brun. 3:3-121.

20. Kocur, M., and T. Martinec. 1972. Taxonomic status of Micrococcus varians Migula 1900 and designation of the neotype strain. Int. J. Syst. Bacteriol. 22:228-232.

21. Kocur, M., and Z. Páčová. 1970. The taxonomic status of Micrococcus roseus Flügge, 1886. Int. J. Syst. Bacteriol. 20:233-240.

22. Komagata, K., and M. Kocur. 1970. Distribution of nucleoside phosphotransferase in staphylococci and micrococci. Zentralbl. Bakteriol. Parasitenk., Infektionskr. Hyg. Abt. 2 124:653-657.

23. Makarova, M. M. 1949. Concerning the new pigmented coccus (in Russian). Mikrobiologiya 18:161-162.

24. Müller, G. 1961. Mikrobiologische Untersuchungen über die "Futterverpilzung durch Selbsterhitzung." III. Mitteilung: Ausführliche Beschreibung neuer Bakterien-Species. Zentralbl. Bak- 
teriol. Parasitenk., Infektionskr. Hyg. Abt. 2 114:520-537.

25. Niebler, E., K. H. Schleifer, and O. Kandler. 1969 The amino acid sequence of the L-glutamic acid containing mureins of Micrococcus luteus and $M$. freudenreichii. Biochem. Biophys. Res. Commun. $34: 560-568$.

26. Pike, E. B. 1965. A trial of statistical methods for selection of determinative characters from Micro. coccaceae isolates. Publ. Fac. Sci. Univ. J. E. Purkynð, Brno K35:316-317.

27. Rosypalová, A., J. Bohácek, and S. Rosypal. 1966. Deoxyribonucleic acid base composition of some micrococci and sarcinae. Antonie van Leeuwenhoek; J. Microbiol. Serol. 32:192-196.

28. Rosypalová, A., J. Bohácek, and S. Rosypal. 1966. Deoxyribonucleic acid base composition and taxonomy of violet-pigmented cocci. Antonie van Leeuwenhoek; J. Microbiol. Serol. 32:105. 112.

29. Schleifer, K. H., and O. Kandler. 1970. Amino acid sequence of the murein of Planococcus and other Micrococcaceae. J. Bacteriol. 103:387-392.

30. Schleifer, K. H., W. E. Kloos, and A. Moore. 1972. Taxonomic status of Micrococcus luteus (Schroeter 1872) Cohn 1872: correlation between peptidoglycan type and genetic compatibility. Int. J. Syst. Bacteriol. 22:224-227.
31. Schroeter, J. 1872. Ueber einige durch Bacterien gebildete Pigmente. Beitr. Biol. Pflanz. 1:109-126.

32. Shaw, C., J. M. Stitt, and S. T. Cowan. 1951. Staphylococci and their classification. J. Gen. Microbiol. 5:1010-1023.

33. Silvestri, L. G., and L. R. Hill. 1965. Agreement between deoxyribonucleic acid base composition and taxometric classification of gram-positive cocci. J. Bacteriol. 90:136-140.

34. Sneath, P. H. A., and V. B. D. Skerman. 1966. A list of type and reference strains of bacteria. Int. J. Syst. Bacteriol. 16:1-133.

35. Sobin, B., and O. L. Stahly. 1942. The isolation and absorption spectrum maxima of bacterial carotenoid pigments. J. Bacteriol. 44: 265-276.

36. Subcommittee on taxonomy of staphylococci and micrococci. 1965. Recommendations. Int. Bull. Bacteriol. Nomencl. Taxon. 15: 109-110.

37. Trevisan, V. 1889. I generi e le specie delle Batteriacee, p. 13-44. Tipo-Lit., L. Zanaboni e Gabuzzi, Milan.

38. Wood, E. J. F. 1952. The micrococci in a marine environment. J. Gen. Microbiol. 6:205-210.

39. ZoBell, C. E., and H. C. Upham. 1944. A list of marine bacteria including descriptions of sixty new species. Bull. Scripps Inst. Oceanogr. 5:239-292. 